\title{
24. TRIASSIC FORAMINIFERS FROM SITES 761 AND 764, WOMBAT PLATEAU, NORTHWEST AUSTRALIA ${ }^{1}$
}

\author{
Louisette Zaninetti, ${ }^{2}$ Rossana Martini, ${ }^{2}$ and Thierry Dumont ${ }^{3}$
}

\begin{abstract}
The Late Triassic foraminifers encountered in the cores from ODP Leg 122 Sites 761 and 764 are, on the basis of Triasina oberhauseri and Triasina hantkeni, late Norian and Rhaetian (Triasina hantkeni Biozone) in age. The reefal carbonate platform penetrated at both sites is characterized by inner shelf (intertidal to lagoon), patch reef, and outer shelf facies.
\end{abstract}

\section{INTRODUCTION}

Upper Triassic sediments were drilled offshore northwest Australia in 1988 during Ocean Drilling Program (ODP) Leg 122 (Haq, von Rad, et al., 1990). Four sites (759, 760, 761, and 764) were drilled on the Wombat Plateau, the northern promontory of the Exmouth Plateau (von Rad et al., 1989a; Fig. 1A). These sites provided the opportunity for reconstructing a composite section of Upper Triassic cores from the Carnian to the Rhaetian, because the Wombat Plateau experienced nondeposition and/or erosion during the whole Jurassic, followed by starved pelagic sedimentation from the Cretaceous to the Holocene. The Triassic sediments, emplaced in a prerift to synrift situation produced by the oceanic opening between India and Australia, are unconformably overlain by the socalled postrift unconformity (Barber, 1988; von Rad et al., $1989 \mathrm{~b})$. The maximum angular unconformity and the deepest erosion occur at the southern Sites 759 and 760, at which only siliciclastic-dominated Carnian (middle to upper) to upper Norian sediments were recovered. This study is based upon the carbonate-rich neritic Rhaetian section with an abundant microfauna that was recovered at Sites 761 and 764 .

\section{UPPER TRIASSIC SERIES}

Detailed sedimentologic studies of the drilled Triassic series can be found in Borella et al. (this volume), Dumont (this volume), and Sarti et al. (this volume). The oldest sediments consist of Carnian silty claystones from a prodelta environment. Their shallowing-upward tendency led during the latest Carnian and Norian times to the episodic development of neritic carbonate wedges, followed at Site 760 by late Norian restricted marginal marine siliciclastics (which confirm the general regressive trend). The depositional evolution was disturbed by a tectonic event that produced extensional deformation of the Carnian deposits and a major depositional gap during part of Norian (early and middle?), which is overlain by a local angular unconformity at Sites 759 and 760 . According to the seismic stratigraphy, the bottom of the cored interval at Site 761 does not overlap the uppermost Triassic cores at Site 760 , but sediments of the same type and age (late Norian pollen and dinoflagellates; Brenner, this volume, chapter 23) were recovered at both sites; thus, there is probably no

\footnotetext{
1 von Rad, U., Haq, B. U., et al., 1992. Proc. ODP, Sci. Results, 122: College Station, TX (Ocean Drilling Program).

2 University of Geneva, 13 rue des Maraîchers, 1211 Genève 4, Switzerland. France.
}

major break between the two. This is in turn overlain at Site 761 by a sharp sedimentary break followed by a new shallowing-upward sedimentary sequence of Rhaetian age, which is capped by the postrift unconformity and comprises schematically two units: (1) a lower, terrigenous-rich, transgressive unit showing both shallow open-marine and external platform environments and (2) an upper regressive carbonate unit with lagoonal to intertidal deposits. A third overlying unit recovered at Site 764 does not exist at Site 761 because of Jurassic erosion. The third unit is generally transgressive and also of Rhaetian age.

\section{RHAETIAN SEQUENCE EVOLUTION AND ENVIRONMENTS}

Seismic stratigraphy and microfacies analysis (Dumont, this volume) show that there is a large overlap between Sites 761 and 764, although the basal Rhaetian sequence boundary was recovered only at Site 761 and the youngest cores were recovered at Site 764. The detailed lateral correlation over a distance of about $20 \mathrm{~km}$ allowed by this overlap improves our knowledge of its sequence evolution. The vertical evolution shows the superposition of two shallowing-upward sequences; the lower one consists of two units interpreted as a transgressive systems tract and a highstand systems tract, respectively, whereas upper sequence, which is preserved only at Site 764 (unit 3), comprises both a transgressive systems tract and a condensed interval, in addition to a possible highstand. Except for the absence of the upper sequence at Site 761, which is an artifact due to later rift tectonics, the main syndepositional lateral changes are due to the greater development of patch reefs at Site 764 (Williamson et al., 1989). However, as shown by Dumont (this volume, fig. 2), these environmental changes do not obliterate the similarities of the sequence evolution at both sites, which can be accurately correlated based upon gamma-ray log and microfacies comparisons.

\section{MICROFAUNAL ANALYSIS}

The stratigraphic distribution of the Triassic (late Norian to Rhaetian) foraminifers has been compared at Sites 761 and 764 . The correlation between the two cored sections (Dumont, this volume) is based on the microfacies, carbonate content, and fragments of megafossils. Based on the foraminifers, the sediments of the lower portion of the two sites can be regarded as upper Norian (Triasina oberhauseri Biozone) and those of the upper portion as Rhaetian (Triasina hantkeni Biozone), up to the contact with the postrift series (Cretaceous to Holocene).

The Triassic section can be subdivided using the foraminiferal analysis (Fig. 1B) into three intervals at both sites. 

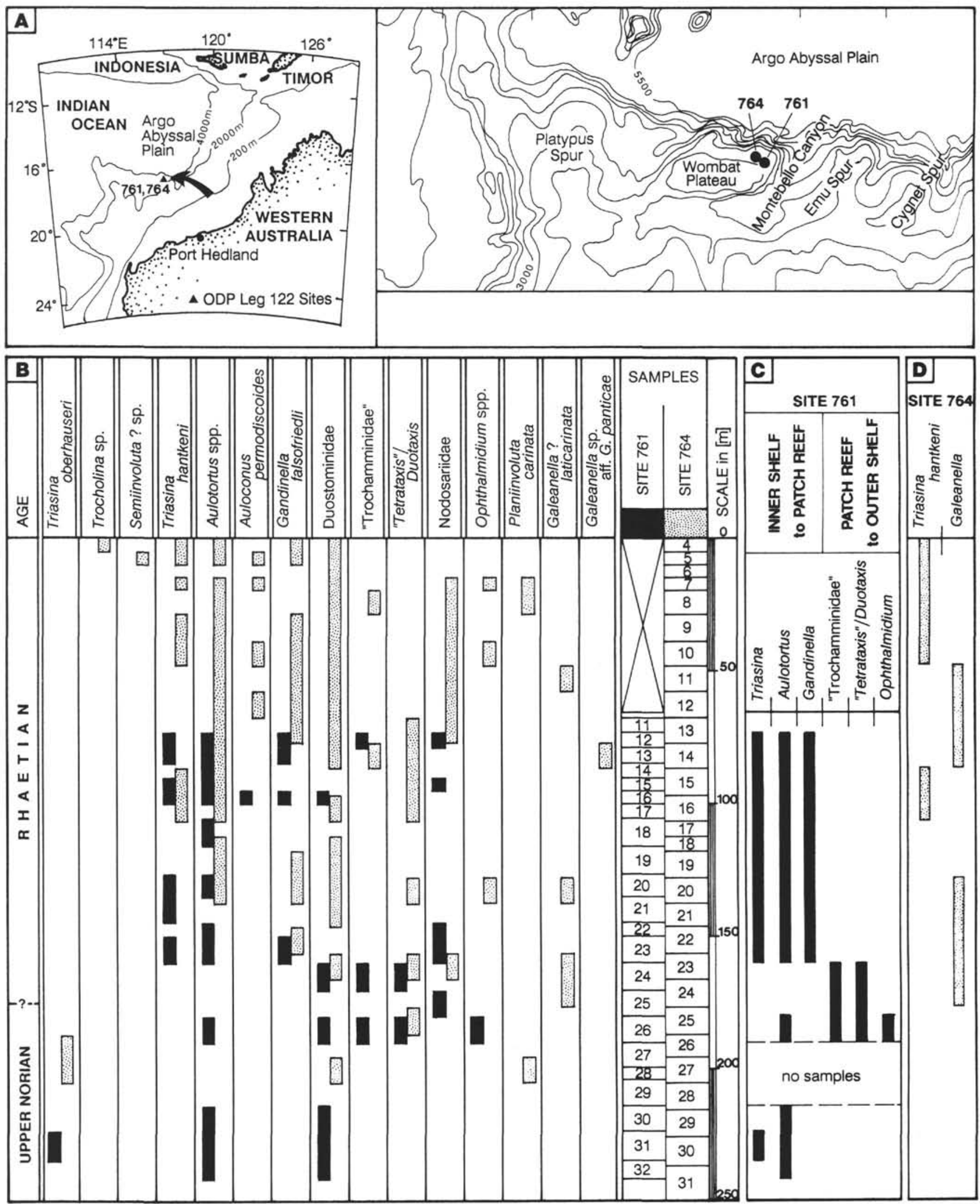

Figure 1. A. Location of Sites 761 and 764. B. Distribution of foraminifers at Sites 761 and 764. C. Alternation of Aulotortidae and Gandinella sp. with other foraminifers at Site 761. D. Alternation of Triasina hantkeni with Galeanella spp. at Site 764. 


\section{Site 761}

The basal interval (Samples 122-761C-32R-CC, 1-5 cm, to $122-761 \mathrm{C}-30 \mathrm{R}-1,7-9 \mathrm{~cm})$ is characterized by a less rich microfauna than that of the upper intervals. The foraminifers are represented by Triasininae (rare Triasina oberhauseri; PI. 1, Fig. 3) and Aulotortinae (Aulotortus communis (Kristan), Aulotortus ex gr. sinuosus (Oberhauser), Aulotortus friedli (Kristan-Tollmann), and Aulotortus spp.; Pl. 2, Figs. 4 and 10-12), normally associated with Duostominidae (Pl. 3, Fig. 1, and Fig. 1B). On the basis of Triasina oberhauseri, we consider this microfauna to be of late Norian age.

The second interval (Samples 122-761C-26R-CC, 16-19 $\mathrm{cm}$, to $122-761 \mathrm{C}-24 \mathrm{R}-1,69-73 \mathrm{~cm}$ ) (we did not study any samples in the interval from Samples 122-761C-29R-CC, 4-6 $\mathrm{cm}$, to $122-761 \mathrm{C}-27 \mathrm{R}-1,41-44 \mathrm{~cm}$ ) is characterized by a marked change in the microfaunal association: the Aulotortidae (Aulotortinae and Triasininae) are either rare or completely absent. The diagnostic foraminifers are "Tetrataxis," Duotaxis birmanica Zaninetti and Brönnimann (see Brönnimann et al., 1975), and Ophthalmidium spp. (PI. 3, Figs. 5-8 and 13). Associated with these forms are Lituolidae?, "Trochamminidae," Textulariidae?, and Endothyridae (PI. 3, Figs. 9-12, 15, and 16). The Duostominidae are common in this interval (Pl. 3, Fig. 3), showing a certain independence with respect to the type of microfacies. They are probably represented by different genera, which are not identifiable in thin section. The microfauna of this intermediate interval does not contain any diagnostic species; hence, it cannot be precisely dated, but its stratigraphic position between the cores with Triasina oberhauseri and with Triasina hantkeni places it in the upper Norian to lower Rhaetian.

The uppermost interval, which begins with Sample 122$761 \mathrm{C}-23 \mathrm{R}-3,40-44 \mathrm{~cm}$, and extends to the top of the hole, is interrupted by an erosional surface within Section 122-761C11R (Fig. 1B). In this third interval, the microfauna is rich and more varied than in the previous intervals. Triasina hantkeni is common (Pl. 1, Fig. 1 and 2), and the main species of Aulotortus have been recorded (Aulotortus communis, Aulotortus friedli, Aulotortus ex gr. sinuosus, Aulotortus impressus (Kristan-Tollmann), and Aulotortus spp.; Pl. 1, Figs. 11 and 12, and Pl. 2, Figs. 1-3 and 5-9), as well as rare Auloconus permodiscoides (Oberhauser) (Core 122-761C16R), Glomospirella spp., Gandinella? sp., and Ammobaculites sp., which are associated with Duostominidae, "Trochamminidae," and Nodosariidae (Fig. 1B). Although it is commonly associated with Aulotortidae in the upper portion at Site 764, Gandinella falsofriedli (Salaj et al., 1983) occurs only sporadically at Site 761 (Pl. 1, Figs. 4-8).

\section{Site 764}

As at Site 761, we also found cores with abundant Aulotortidae alternating with cores in which only smaller foraminifers occur at Site 764. These alternations, however, are less obvious than at Site 761 (Fig. 1C). They are due to the varying carbonate content at both sites. Where the sediments are carbonate rich, the Aulotortidae are predominant. Site 764 is further characterized by the common occurrence of Auloconus permodiscoides and by the appearance of Galeanella? laticarinata Al-Shaibani, Carter, and Zaninetti. These forms are commonly associated with "Tetrataxis," Duotaxis birmanica, and Ophthalmidium spp.

The basal carbonate interval, between Core 122-764B-31R and Sample 122-764B-27R-1, 91-104 cm (Fig. 1B), can be compared in full with the basal interval at Site 761 (Core $122-764 B-32 R$ to Sample 122-764B-30R-1, 64-67 cm). It is characterized by Triasina oberhauseri (Pl. 4, Fig. 1) and
Aulotortus sp. in association with Planiinvoluta carinata Leischner and Duostominidae. The age of this interval is probably late Norian on the basis of the occurrence of Triasina oberhauseri.

The second interval extends from Samples 122-764B26R-1, 58-60 cm, to 122-764B-21R-CC, 18-21 cm, and ends before the abundant occurrence of the Aulotortidae. In this interval, the smaller foraminifers predominate. They are represented by Nodosariidae, Ataxophragmiidae?, Duostominidae, "Trochamminidae," Miliolidae?, "Tetrataxis" sp., Duotaxis birmanica, Ophthalmidium spp., and Galeanella? laticarinata, which first appears in Core 122-764B-24R (Pl. 4, Fig. 6, Pl. 5, Figs. 1-3 and 5, and Fig. 1B). In Core 122-764B$22 \mathrm{R}$, we found Gandinella falsofriedli, which normally occurs together with Aulotortidae, as in the upper interval. The age of this intermediate interval is late Norian? to early Rhaetian.

The third interval extends from Sample 122-764B-20R-1, $106-109 \mathrm{~cm}$, to the top of the cored section (Fig. 1B). This interval is dominated by the Aulotortidae: Aulotortus sinuosus, Aulotortus communis, Aulotortus spp., Auloconus permodiscoides, and Triasina hantkeni, which was recorded previously in Core 122-764B-16R (Pl. 4, Figs. 2-5). The Aulotortidae commonly occur together with Nodosariidae, Duostominidae (Pl. 4, Figs. 8-10 and 15), and particularly Gandinella falsofriedli (Pl. 4, Figs. 11-14). In Core 122-764B$14 \mathrm{R}$, we also found Galeanella sp. aff. G. panticae Zaninetti and Brönnimann associated with the Aulotortidae. Interruptions in the distribution of the microfaunas dominated by the Aulotortidae are characterized by the development of small foraminifers with microgranular or porcelaneous walls, such as "Trochamminidae," Endothyridae, small miliolids, "Tetrataxis' inflata Kristan, Duotaxis birmanica, Ophthalmidium spp., Planiinvoluta carinata, Planiinvoluta? irregularis Salaj, Samuel, and Borza, and Galeanella? laticarinata (Pl. 4, Fig. 7, and Pl. 5, Figs. 6-10 and 17-21). At the top of Site 764, Trocholina sp. is present, as well as a doubtful form, tentatively placed in Semiinvoluta Kristan.

\section{MICROPALEONTOLOGICAL COMPARISON BETWEEN SITES 761 AND 764}

The microfaunal analysis shows an overall similarity between the two sites, with the predominance of the Aulotortidae at the base and, particularly, at the top of the sections. Duostominidae and Nodosariidae occur at both sites. They are, however, more common at Site 764. Also, the group "Tetrataxis"-Duotaxis and above all the Miliolina, represented at Site 761 only by Ophthalmidium spp., are more common at Site 764. Galeanella? and Planiinvoluta were not observed in Site 761. This is perhaps an indication of a more external reefal sedimentation at Site 764 . We further observed at Site 764 a regular alternation of cores with Triasina hantkeni and cores with Galeanella? laticarinata (Fig. 1D), which clearly shows that these species are restricted to paleoecologically different environments. It seems that Triasina hantkeni occurs in more internal, lagoonal subenvironments of the reefal platform, whereas Galeanella? laticarinata appears to be restricted to patch reefs and their immediate neighborhood.

On the other hand, as far as microfaunal distribution is concerned, we find a difference in the occurrence of the Aulotortidae in the two sections. Aulotortus spp., Auloconus permodiscoides, and in particular Triasina oberhauseri and Triasina hantkeni appear about $10 \mathrm{~m}$ deeper at Site 761 than at Site 764. A similar difference in depth of occurrence was also found for Ophthalmidium, the Duostominidae, the "Trochamminidae," and the Nodosariidae. Gandinella falsofriedli, however, first appears in both sections at approximately the same level. 


\section{MICROPALEONTOLOGICAL COMPARISON WITH OTHER TRIASSIC TETHYAN LOCALITIES}

The northwest Australian Triassic foraminiferal fauna shows the closest affinity with that of the Indonesian locality of Seram (Al-Shaibani et al., 1984). The more important species of the Rhaetian of Seram are Triasina hantkeni, which is abundant, several species of Aulotortus, Duostominidae, and "Trochamminidae." The other biostratigraphically significant species that occur, but are typically rare in the Upper Triassic of the Tethys, are "Tetrataxis" inflata, Duotaxis birmanica, which was originally recorded in the Upper Triassic of Burma, and Galeanella? laticarinata, which was first described from Seram (Al-Shaibani et al., 1983) and seems to be paleogeographically restricted to the Eastern Tethys. The northwest Australian occurrence of this species is apparently the first record from outside Seram. On the other hand, Miliolipora cuvillieri Brönnimann and Zaninetti and thickwalled galeanellas, both relatively abundant in the reefal Triassic of Seram, are absent at the Australian Wombat Plateau.

It has to be pointed out that the micropaleontological similarities between the Indonesian and Australian localities require further stratigraphic investigation in order to establish the paleogeography of the Upper Triassic carbonate platforms in the Eastern Tethys realm. However, the presence of Triasina hantkeni permits the identification of the Rhaetian interval at both localities. The characteristic species, Galeanella? laticarinata, considered to be Norian-Rhaetian in age at the type locality of Seram, occurs at Site 764 in the same stratigraphic interval containing Triasina hantkeni. This allows us to establish a Rhaetian age for Galeanella? laticarinata on the Wombat Plateau and probably as well for the Upper Triassic locality of Seram.

The microfaunas from Sites 761 and 764 also have a certain resemblance to those of Late Triassic age from the Caucasus (Efimova, 1974, 1975), at least concerning Aulotortus spp., Auloconus, "'Tetrataxis," Ophthalmidium, "Trochamminidae,' Duostominidae, and Nodosariidae. In the Caucasus area Triasina hantkeni seems to be absent, but other foraminifers reported by Efimova were not found on the Wombat Plateau-in particular, Miliolipora, Sigmoilina, and Agathammina.

The Rhaetian of New Guinea (Kristan-Tollmann, 1986) also contains microfaunas that, in part, can be compared to those from northwest Australia. At the New Guinea locality, on the basis of the illustrations, the Aulotortidae and the Glomospirellas seem to predominate and the new species described from the Rhaetian of New Guinea-Glomospirella wahgiensis Kristan-Tollmann-looks very similar to Gandinella falsofriedli and is probably a junior synonym. Miliolina, with Planiinvoluta and Miliolipora, and the Duostominidae are also present in New Guinea.

The microfaunas of the Wombat Plateau are also related to those from the Upper Triassic of China ( $\mathrm{He} \mathrm{Yan}$ and $\mathrm{Hu}$ Lan-Ying, 1977; He Yan, 1982), as shown by the occurrence at the Chinese localities of "Trochamminidae," "Tetrataxis," Glomospirella, Aulotortus spp., Duostominidae, and Nodosariidae. As for as the distribution of Triasina hantkeni in the Eastern Tethys is concerned, the species has also been described in China (He Yan, 1980) and in the Philippine Islands (Fontaine et al., 1979; see also Al-Shaibani et al., 1982).

In contrast to the aforementioned localities, the microfaunas described by Heath and Apthorpe (1986) from the Lower? and Middle Triassic of the Northwest Shelf, Western Australia, are dominated by the Nodosariidae and differ strongly from those of the Wombat Plateau. They show, in our opinion, more of a Jurassic (Cretaceous?) affinity than that of the Triassic.

Finally, there is no similarity to either the Late Triassic microfaunas from the shallow carbonate platform drilled during ODP Leg 122 or the Late Triassic (probably Rhaetian) foraminifers from the northern Exmouth Plateau, northwest Australia, studied by Kristan-Tollmann and Gramann (this volume). The occurrence in this latter locality of rare Aulotortidae ("Glomospirella" friedli $=$ Aulotortus friedli) and abundant Involutinidae (Involutina liassica, Involutina turgida, Trocholina turris, Trocholina crassa, and Coronipora austriaca) suggests a deeper sedimentary environment than that of the assemblages from Sites 761 and 764 on the Wombat Plateau, ranging from outer shelf to basin, according to the paleoecology of the Involutinidae in the Alps (see also Piller, 1978).

\section{PALEOECOLOGICAL AND STRATIGRAPHIC CONCLUSIONS}

\section{Paleoecology}

The alternating occurrence at Sites 761 and 764 of Aulotortidae (Aulotortus, Auloconus, and Triasina) and smaller foraminifers (Duotaxis, "Tetrataxis," "Trochamminidae," and Ophthalmidium) is characteristic of reefal platforms. This environment can, however, be differentiated into an inner zone (lagoon to patch reef), with abundant Aulotortidae, and a more external zone (patch reef to outer shelf) with small microgranular or porcelaneous foraminifers (Fig. 1C).

The occurrence of Galeanella? laticarinata in several cores at Site 764 places this site in a more external reefal environment than that of Site 761, where lagoonal facies with Aulotortidae are predominant.

\section{Stratigraphy}

On the basis of Triasina oberhauseri and Triasina hantkeni, the samples examined from both Sites 761 and 764 are of late Norian to Rhaetian age. Triasina oberhauseri has been reported from various Norian localities of the Western Tethys (Koehn-Zaninetti and Brönnimann, 1968; Brönnimann et al., 1970; Abate et al., 1984) and Triasina hantkeni defines the Rhaetian Triasina hantkeni Biozone (Gazdzicki et al., 1979; Gazdzicki, 1983; Gazdzicki and Reid, 1983; Abate et al., 1984; Ciarapica and Zaninetti, 1984; Vachard and Fonatine, 1988) throughout the Tethyan realm.

\section{ACKNOWLEDGMENTS}

Micropaleontological analysis was financially supported by the Swiss National Foundation (LZ, grant no. 21-27'699.89).

\section{REFERENCES}

Abate, B., Ciarapica, G., and Zaninetti, L., 1984. Triasina oberhauseri Koehn-Zaninetti et Brönnimann, 1968, dans le Trias supérieur récifal (facies 'back-reef") de la plate-forme Panormide, Sicile. Rev. Paleobiol., 3:19-25.

Al-Shaibani, S., Altiner, D., Brönnimann, P., Carter, D. J., and Zaninetti, L., 1982. Triasina hantkeni Majzon, 1954 (Foraminifère), dans le Trias supérieur de la Téthys (Europe et Asie). Arch. Sci., 35:137-142.

Al-Shaibani, S., Carter, D. J., and Zaninetti, L., 1983. Geological and micropaleontological investigations in the Upper Triassic (Asinepe Limestone) of Seram, Outer Banda Arc, Indonesia. Arch. Sci., 36:297-313.

1984. Microfaunes associées aux Involutinidae et aux Milioliporidae dans le Trias supérieur (Rhétien) de Seram, Indonésie; précisions stratigraphiques et paléoécologie. Arch. Sci., 37:301-316. 
Barber, P. M., 1988. The Exmouth Plateau deep water frontier: a case history. In Purcell, P. G., and Purcell, R. R. (Eds.), The North West Shelf, Australia: Proc. Pet. Expl. Soc. Aust. Symp., 173-187.

Brönnimann, P., Poisson, A., and Zaninetti, L., 1970. L'Unité de Domuz Dag (Taurus lycien-Turquie); microfaciès et Foraminiferes du Trias et du Lias. Riv. Ital. Paleontol., 76:1-36.

Brönnimann, P., Whittaker, J. E., and Zaninetti, L., 1975. Triassic foraminiferal biostratigraphy of the Kyaukme-Longtawkno area, Northern Shan States, Burma. Riv. Ital. Paleontol., 81:1-30.

Ciarapica, G., and Zaninetti, L., 1984. Foraminifères et biostratigraphie dans le Trias supérieur de la serie de La Spezia (Dolomies de Coregna et Formation de La Spezia, nouvelles formations), Apennin septentrional. Rev. Paleobiol., 3:117-134.

Efimova, N. A., 1974. Triassic foraminifers of the NW Caucasus and Cis-Caucasus. Akad. Nauk. SSSR, Vopr. Mikropal., 17:54-83. 1975. Foraminifères des dépts de la série de Khodzin. In Buznacov, N. V. (Ed.), Nouvelles Données Stratigraphiques des Dépts Mésozoiques Contenant du Gaz et du Pétrole: Régions du Sud de l'URSS. Trav. Minist. Geol., 171:47-61.

Fontaine, H., Beauvais, L., Poumint, C., and Vachard, D., 1979. Données nouvelles sur le Mésozoque de l'Ouest des Philippines. Découverte de Rhétien marin. Bull. Soc. Geol. Fr., Suppl., 3:117-121.

Gazdzicki, A., 1983. Foraminifers and biostratigraphy of Upper Triassic and Lower Jurassic of the Slovakian and Polish Carpathians. Paleontol. Pol., 44:109-169.

Gazdzicki, A., Kuzur, H., and Mock, R., 1979. The Norian-Rhaetian boundary in the light of micropaleontological data. Geologija, 22:71-112.

Gazdzicki, A., and Reid, P., 1983. Upper Triassic Involutinidae (foraminifers) of Lime Peak in Yukon, Canada. Acta Geol. Pol., 33:99-106.

Gazdzicki, A., and Smit, O. E., 1977. Triassic foraminifers from the Malay Peninsula. Acta Geol. Pol., 27:319-332.

Haq, B. U., von Rad, U., O'Connell, S., 1990. Proc. ODP, Init. Repts., 122: College Station, TX (Ocean Drilling Program).

Heath, R. S., and Apthorpe, M. C., 1986. Middle and Early (?) Triassic foraminifera from the Northwest Shelf, Western Australia. J. Foraminiferal Res., 16:313-333.

He Yan, 1980. Sketch of the Triassic foraminiferal biostratigraphy of NW Sichuan (Szechuan), China. Riv. Ital. Paleontol., 85:1167-1174.
1982. Upper Triassic Foraminifers of eastern Xizang. In Stratigraphy and Paleontology in W. Sichuan and E. Xizang (pt. 2): Sichuan, China (The People's Publishing House).

$\mathrm{He}$ Yan and Hu Lang-Ying, 1977. Triassic foraminifers from the area in the east flank of the Lancanging River, Yunnan. In Mesozoic Fossils from Yunnan, China (pt. 2): Cent. Rech. Geol. Fossiles Acad. Sci. Chine à Nankin. Traduction de l'Inst. Fr. Pet., Réf. 26193, 1978

Koehn-Zaninetti, L., and Brönnimann, P., 1968. Triasina oberhauseri, n. sp., un Foraminifère de la Dolomie Principale des Alpes Calcaires septentrionales (Autriche). Publ. Inst. Paleont. Univ. Genève, Imprimerie Fontana, 1-8.

Kristan-Tollmann, E., 1986. Foraminiferen aus dem rhtischen KutaKalk von Papua/Neuguinea. Mitt. Oesterr. Geol. Ges., 78:291317.

Piller, W., 1978. Involutinacea (foraminifers) der Trias und des Lias. Beitr. Palaontol. Oesterr., 5:1-164.

Salaj, J., Borza, K., and Samuel, O., 1983. Triassic foraminifers of the West Carpathians. In Gasparikova, V. (Ed.), Geologicky Ustav Dionyza Stura: Bratislava.

Vachard, D., and Fontaine, H., 1988. Biostratigraphic importance of Triassic foraminifers and algae from South-East Asia. Rev. Paleobiol., 7:87-98.

von Rad, U., Haq, B. U., and Leg 122 Shipboard Scientific Party, 1989a. Breakup of Gondwanaland. Nature, 337:209-210.

von Rad, U., Thurow, J., Haq, B. U., Gradstein, F., Ludden, J., and ODP Leg 122/123 Shipboard Scientific Parties, 1989b. Triassic to Cenozoic evolution of the NW Australian continental margin and the birth of the Indian Ocean (preliminary results of ODP Legs 122 and 123). Geol. Rundsch., 78:1189-1210.

Williamson, P. E., Exon, N. F., Haq, B. U., von Rad, U., O'Connell, S., and Leg 122 Shipboard Scientific Party, 1989. A Northwest Shelf Triassic reef play: results from ODP Leg 122. APEA J., 29:328-344.

Date of initial receipt: 11 May 1990

Date of acceptance: 29 January 1991

Ms 122B-173 

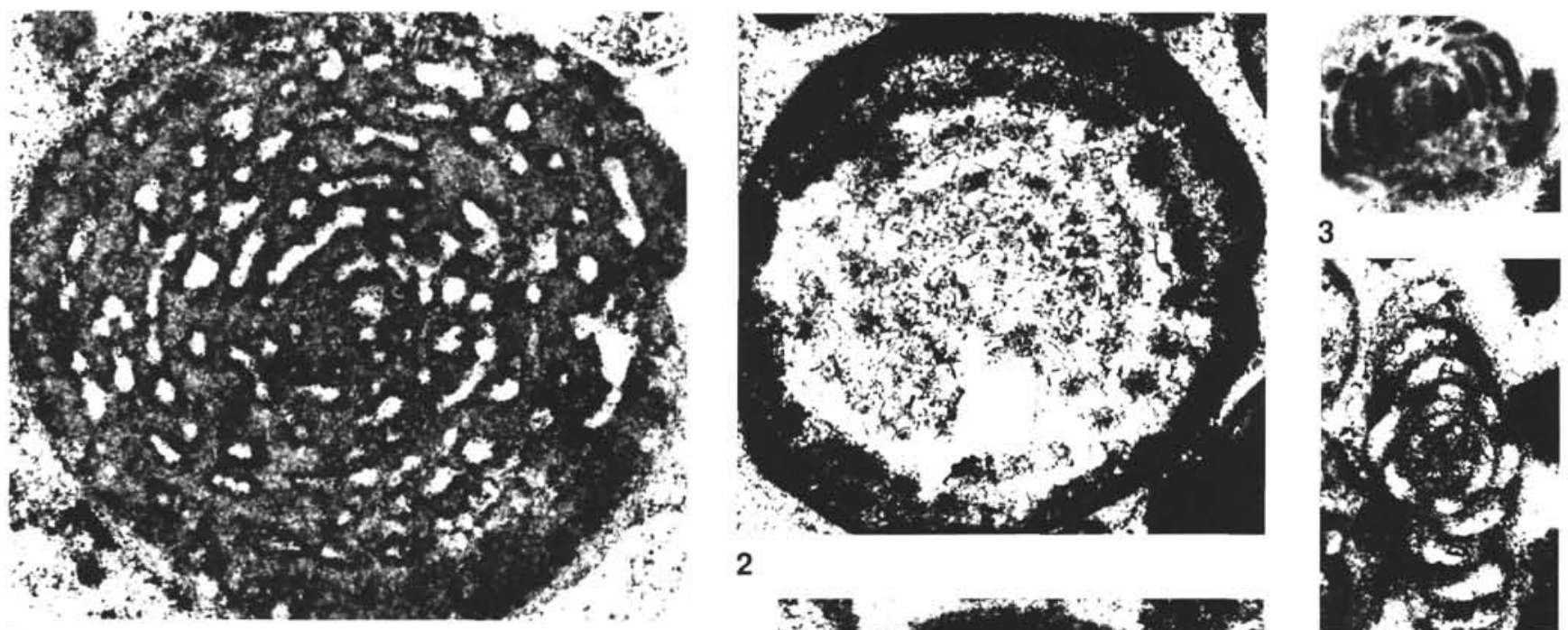

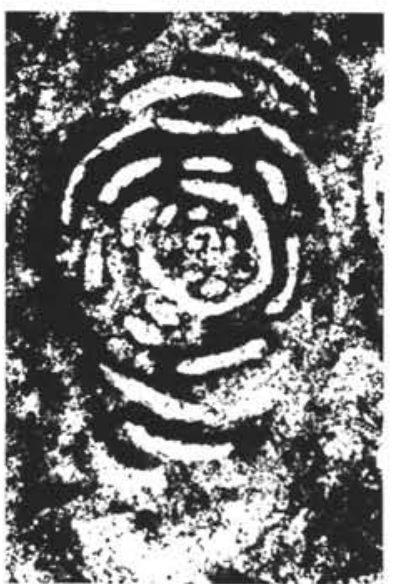

6

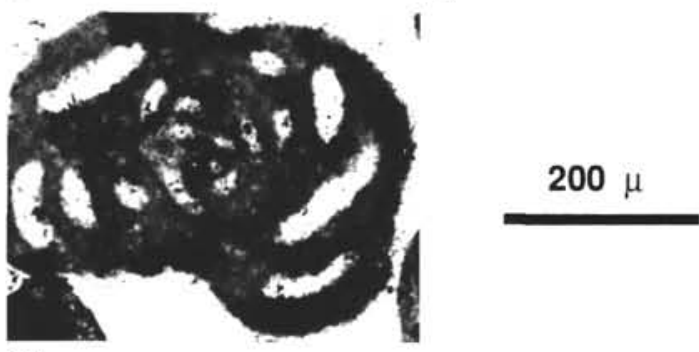

10

7

8
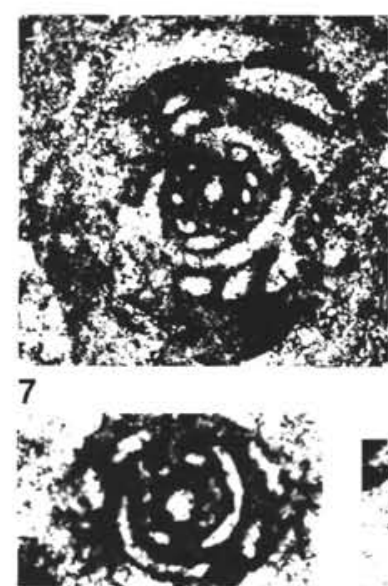

2
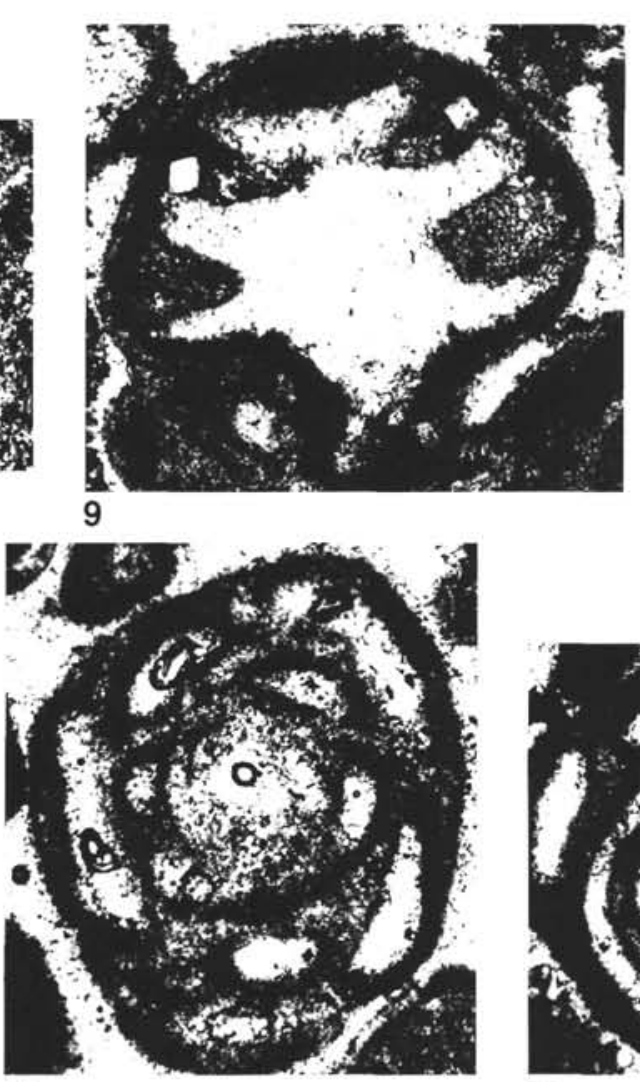

11
3

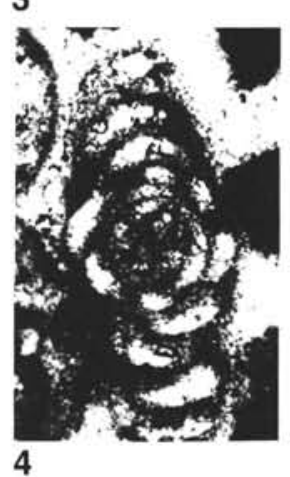

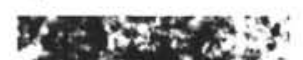

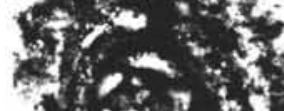

5 is

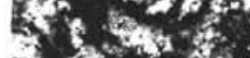

7. 6. onst?

5. Sintin

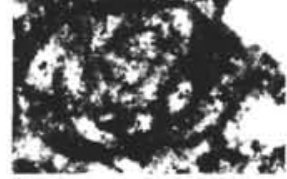

5

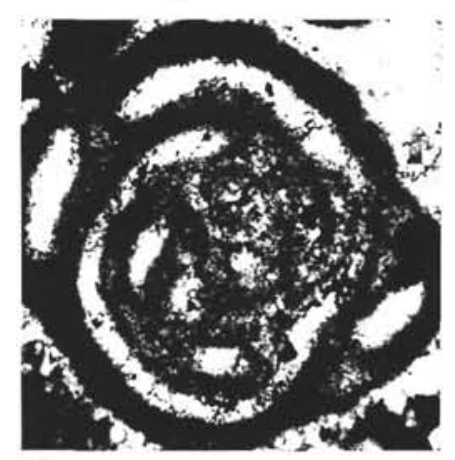

12

Plate 1. 1, 2. Triasina hantkeni Majzon; (1) Sample 122-761C-16R-1, 23-26 cm, (2) Sample 122-761C-12R-1, 16-19 cm. 3. Triasina oberhauseri Koehn-Zaninetti and Brönnimann, Sample 122-761C-32R-3, 2-4 cm. 4. Gandinella sp. aff. G. falsofriedli (Salaj, Borza, and Samuel), Sample 122-761C-13R-1, 6-9 cm. 5. Gandinella falsofriedli (Salaj, Borza, and Samuel), Sample 122-761C-13R-1, 1-3 cm. 6-8. Gandinella? sp., Sample 122-761C-16R-1, 23-26 cm. 9. Auloconus? sp., Sample 122-761C-16R-1, 52-55 cm. 10. Indeterminate foraminifer, Sample 122-761C-12R-1, 16-19 cm. 11, 12. Aulotortus friedli? (Kristan-Tollmann), micritized specimen, Sample 122-761C-12R-1, 16-19 cm. 


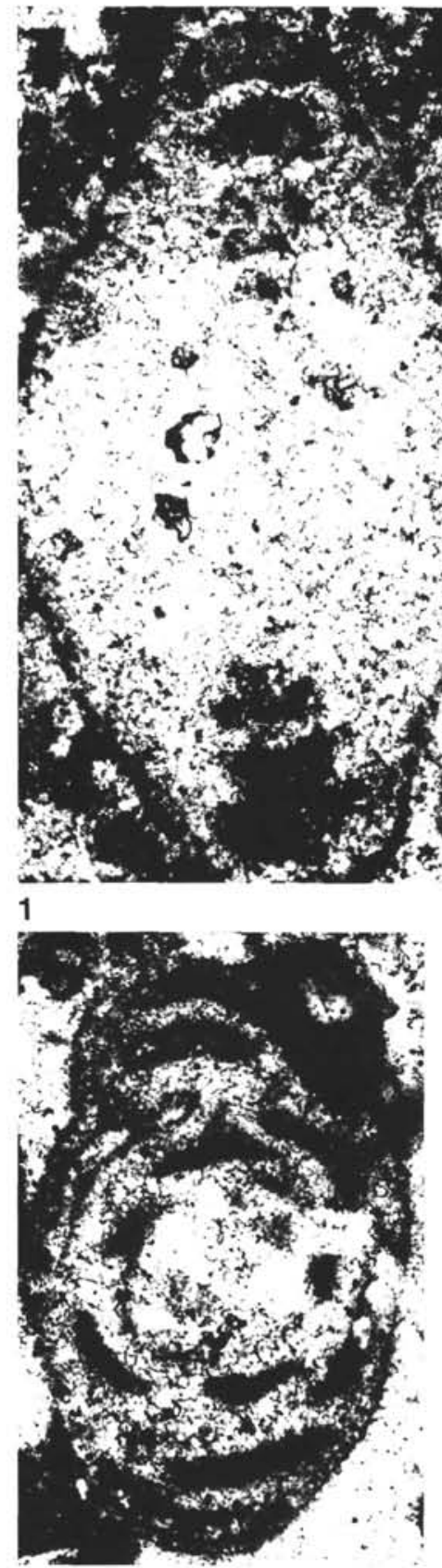

5

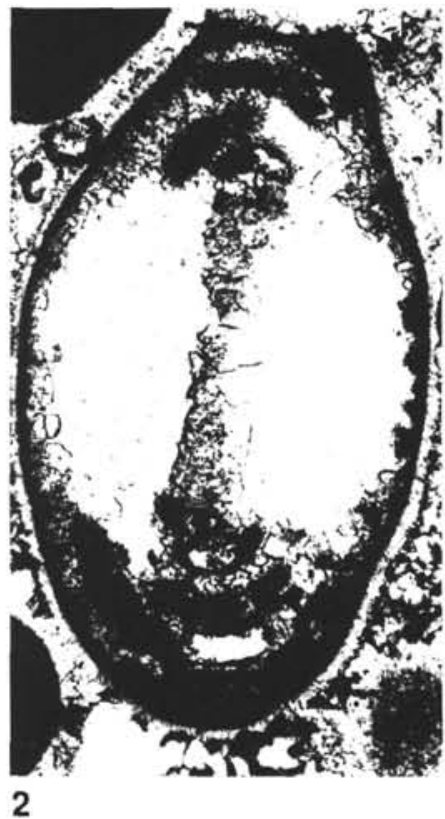

$200 \mu$

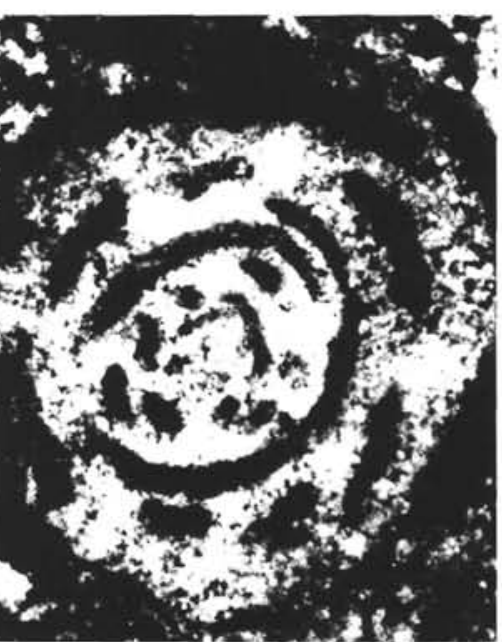

6
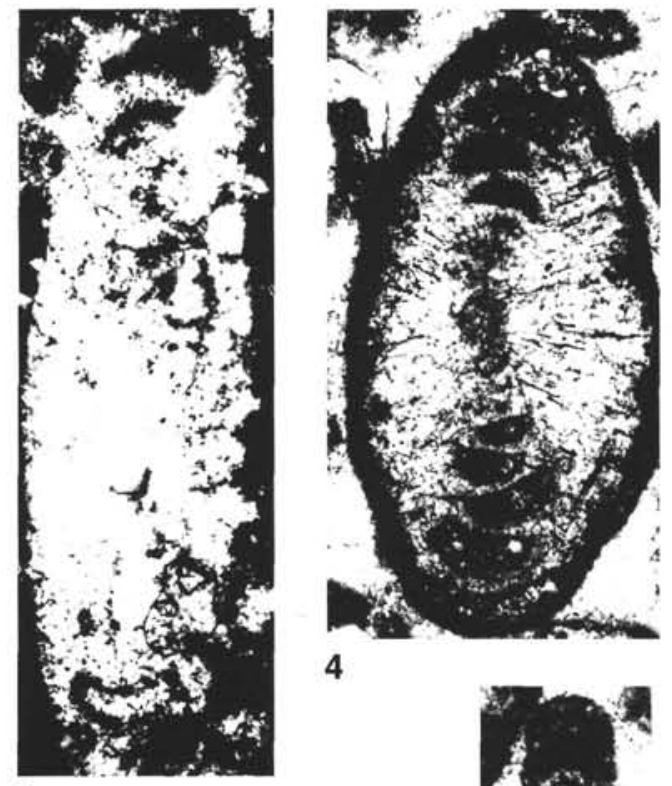

4

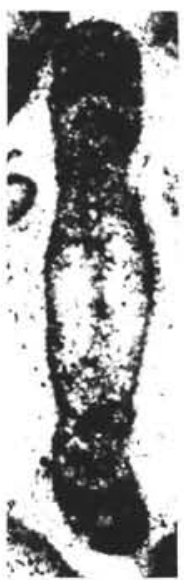

9

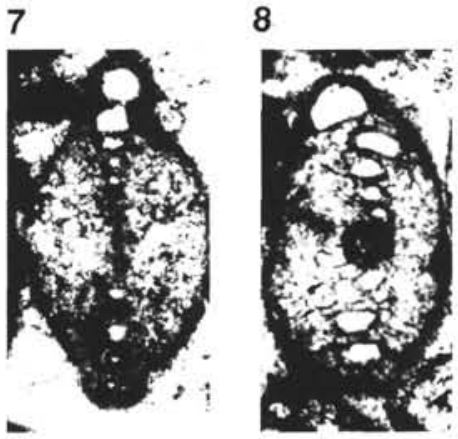

11
12

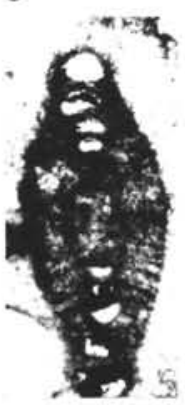

Plate 2. 1, 2, 4. Aulotortus sinuosus pragsoides (Oberhauser); (1) Sample 122-761C-13R-1, 1-3 cm, (2) Sample 122-761C-12R-1, 16-19 cm, (4) Sample 122-761C-32R-CC, 3-5 cm. 3. Aulotortus aff. tenuis (Kristan), Sample 122-761C-15R-1, 44-47 cm. 5, 6. Aulotortus friedli (Kristan-Tollmann); (5) Sample 122-761C-16R-1, 52-55 cm, (6) Sample 122-761C-13R-1, 1-3 cm. 7, 8, 10-12. Aulotortus communis (Kristan); (7, 8) Sample 122-761C-16R-1, 52-55 cm, (10-12) Sample 122-761C-31R-CC, 3-5 cm. 9. Aulotortus tumidus (Kristan-Tollmann), Sample 122-761C-13R-1, 6-9 cm. 


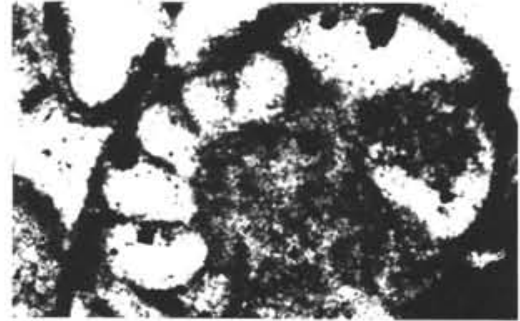

1

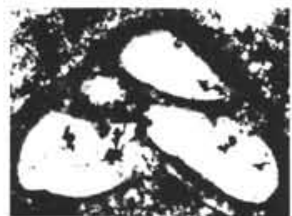

5

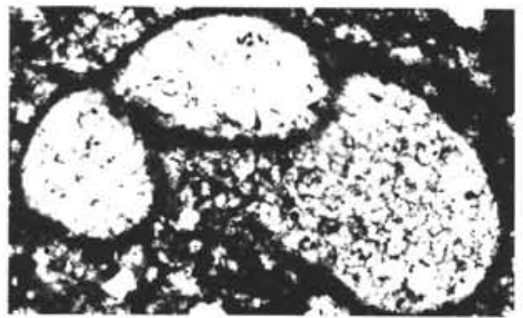

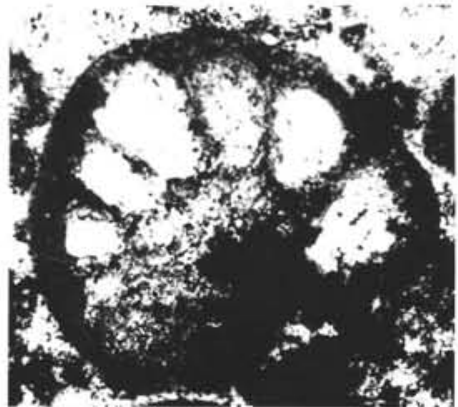

2

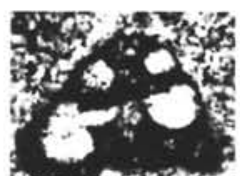

ins

7

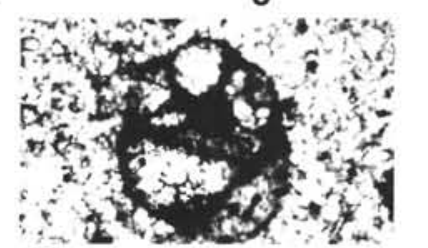

$10 *$

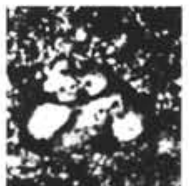

8

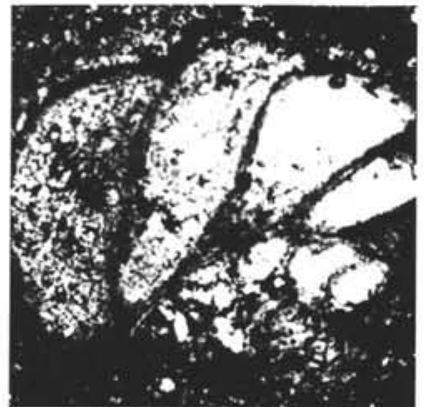

3

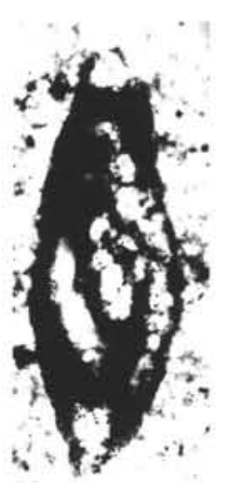

13 *

$$
9 *
$$
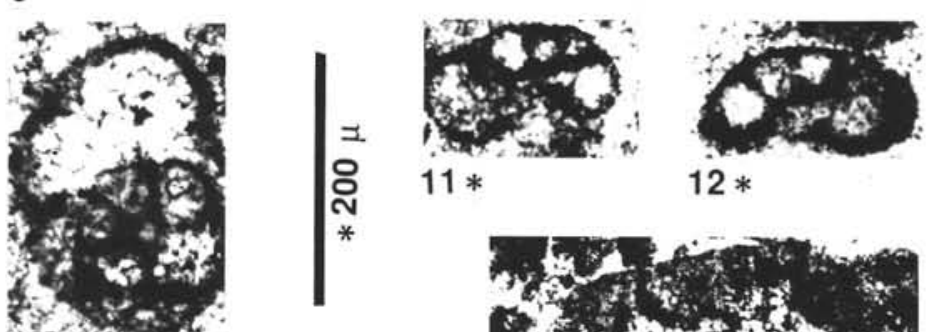

$12 *$

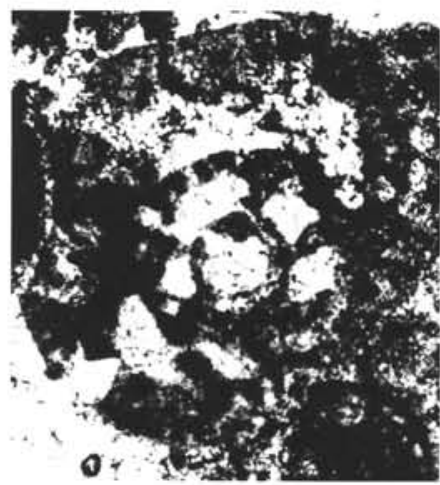

18

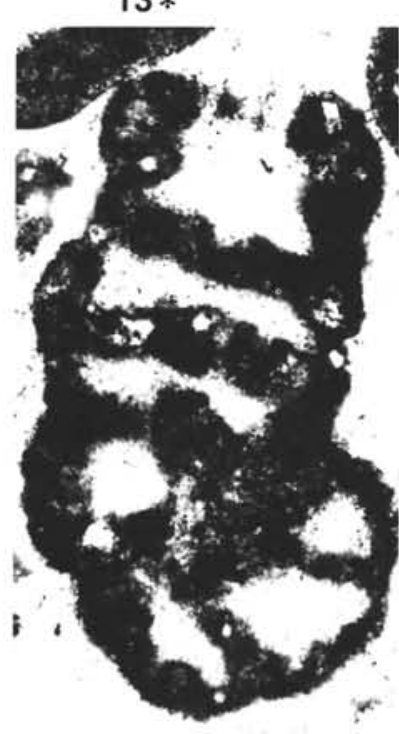

19

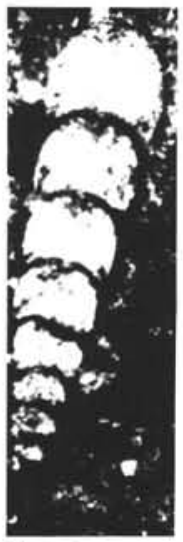

4

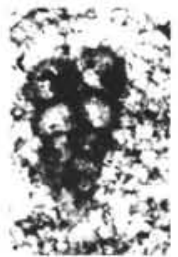

$15 *$

$14 *$
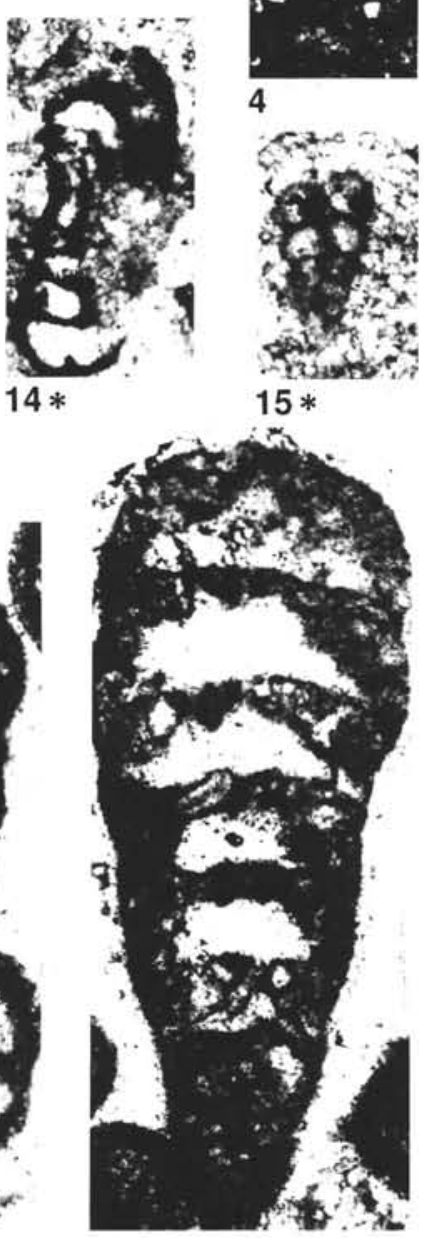

20

Plate 3. 1-3. Duostominidae; (1) Sample 122-761C-32R-3, 2-4 cm, (2) Sample 122-761C-16R-1, 52-55 cm, (3) Sample 122-761C-24R-1, 69-73 $\mathrm{cm}$. 4. Nodosariidae, Sample 122-761C-15R-1, 44-47 cm. 5. Duotaxis birmanica Zaninetti and Brönnimann in Brönnimann et al. (1975), Sample 122-761C-24R-1, 69-73 cm. 6-8. "Tetrataxis?" sp.; (6) Sample 122-761C-24R-CC, 11-15 cm, (7, 8) Sample 122-761C-24R-1, 69-73 cm. 9. "Trochamminidae" or Duostominidae, Sample 122-761C-26R-CC, 16-19 cm. 10-12. "Trochamminidae?"; (10) Sample 122-761C26R-4, 65-67 cm, (11, 12) Sample 122-761C-26R-1, 1-4 cm. 13. Ophthalmidium sp., Sample 122-761C-26R-4, 65-67 cm. 14, 17. Indeterminate foraminifers; (14) Sample 122-761C-26R-1, 1-4 cm, (17) Sample 122-761C-26R-4, 65-67 cm. 15. Textulariidae?, Sample 122-761C-26R-6, 136-139 cm. 16. Endothyridae, Sample 122-761C-26R-6, 136-139 cm. 18. Lituolidae?, Sample 122-761C-16R-1, 23-26 cm. 19, 20. Ammobaculites sp., Sample 122-761C-12R-1, 16-19 cm. 


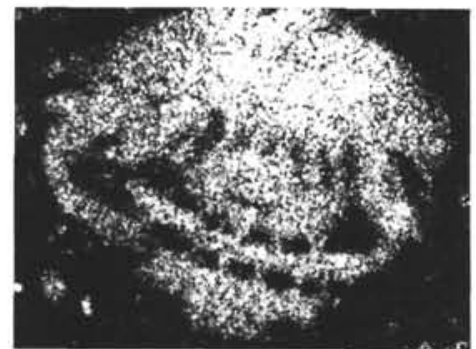

1

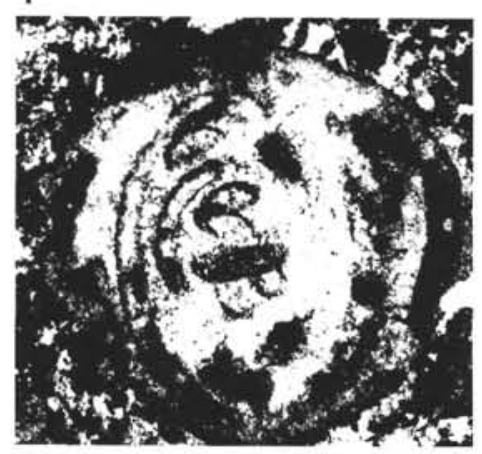

5

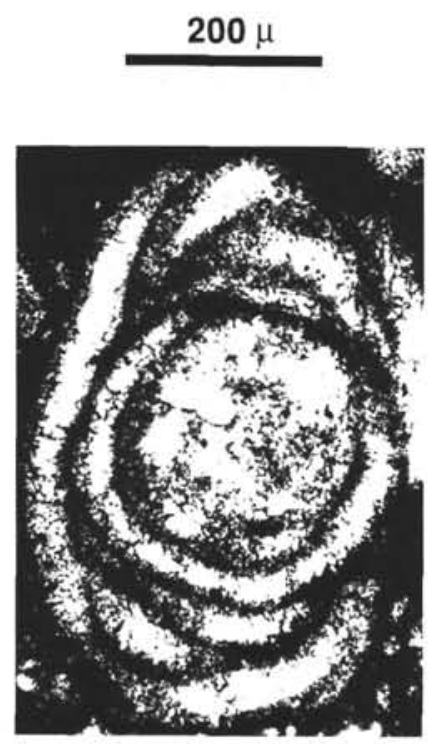

13

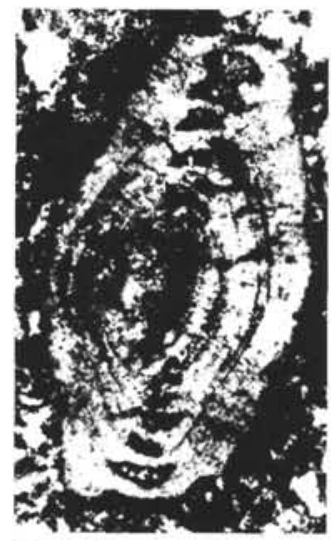

2

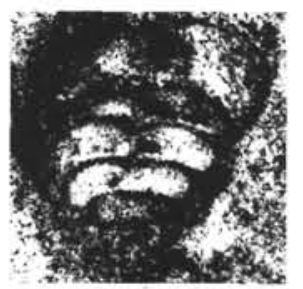

6

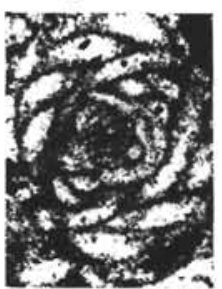

11

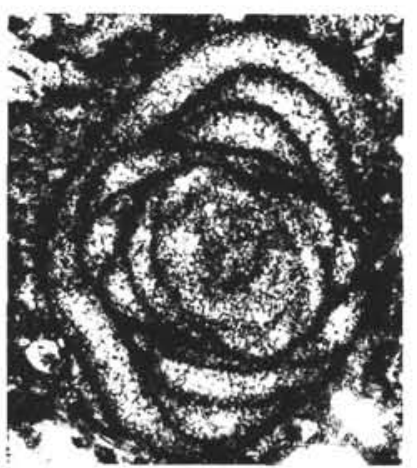

14

12

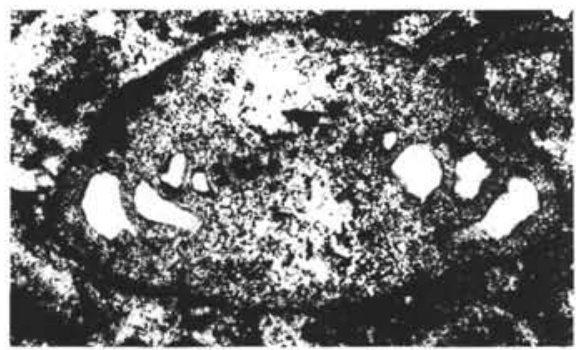

3

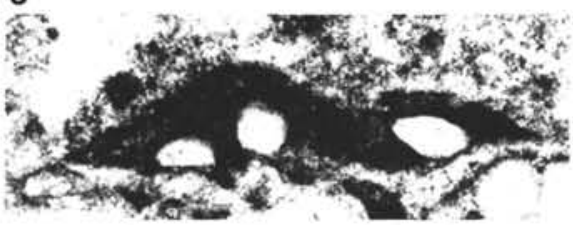

7

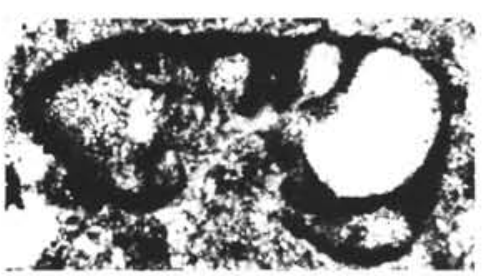

8
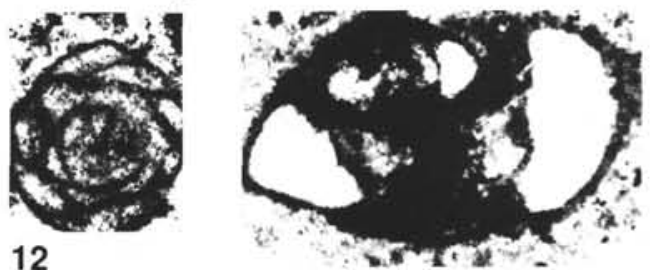

9

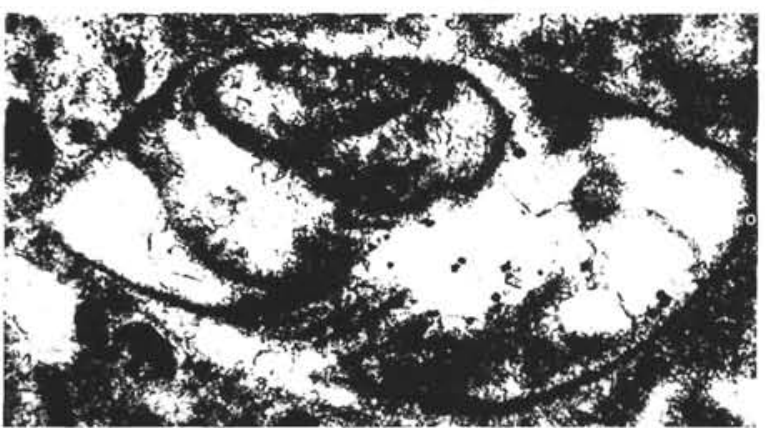

15

Plate 4. 1. Triasina oberhauseri Koehn-Zaninetti, and Brönnimann, Sample 122-764B-27R-1, 60-64 cm. 2. Aulotortus communis (Kristan), Sample 122-764B-5R-1, 43-47 cm. 3. Auloconus permodiscoides (Oberhauser), Sample 122-764B-5R-1, 9-13 cm. 4. Aulotortus? sp., Sample 122-764B-8R-CC, 4-8 cm. 5. Aulotortus friedli (Kristan-Tollmann), Sample 122-764B-7R-1, 24-27 cm. 6. Ataxophragmiidae, Sample 122-764B-23R-1, 72-76 cm. 7. Planiinvoluta? irregularis Salaj, Borza, and Samuel, Sample 122-764B-14R-CC, 5-8 cm. 8-10. Duostominidae, Sample 122-764B-8R-CC, 25-29 cm. 11, 12. Gandinella falsofriedli (Salaj, Borza, and Samuel), Sample 122-764B-5R-1, 9-13 cm. 13, 14. Gandinella? sp.; (13) Sample 122-764B-11R-1, 4-7 cm, (14) Sample 122-764B-10R-1, 10-15 cm. 15. Duostominidae with two-layered wall, Sample 122-764B-14R-CC, $5-8 \mathrm{~cm}$. 


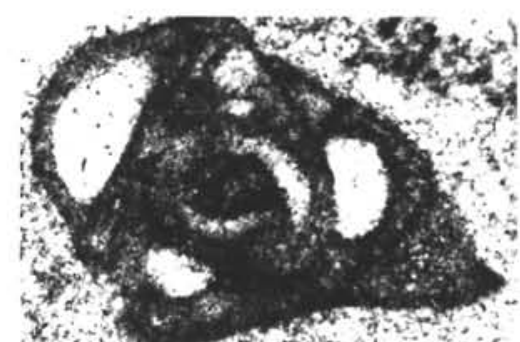

1

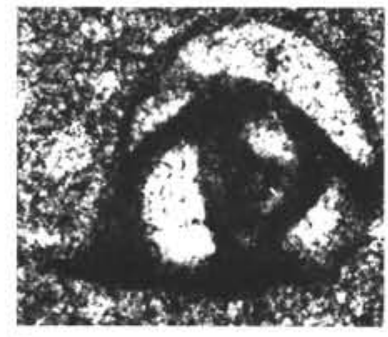

5

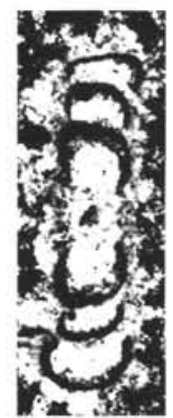

11

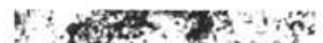

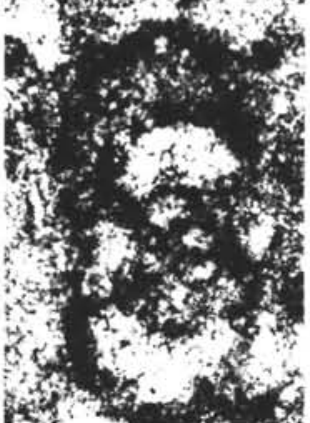

18

6 7

13

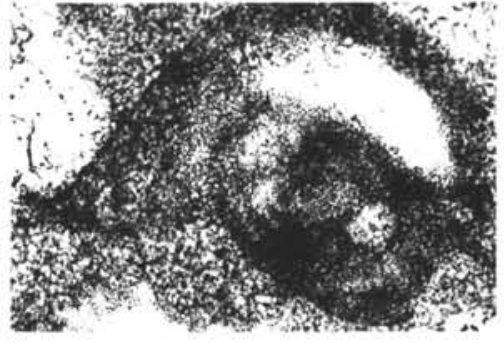

2

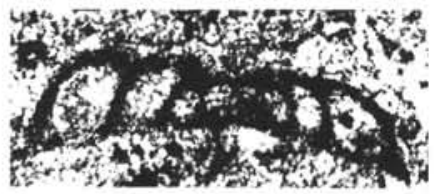

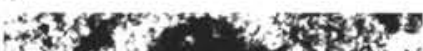

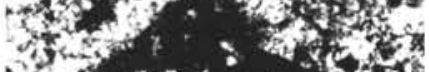

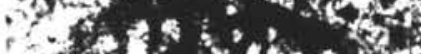

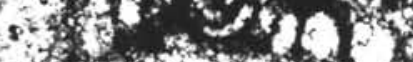

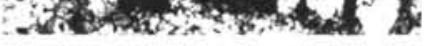
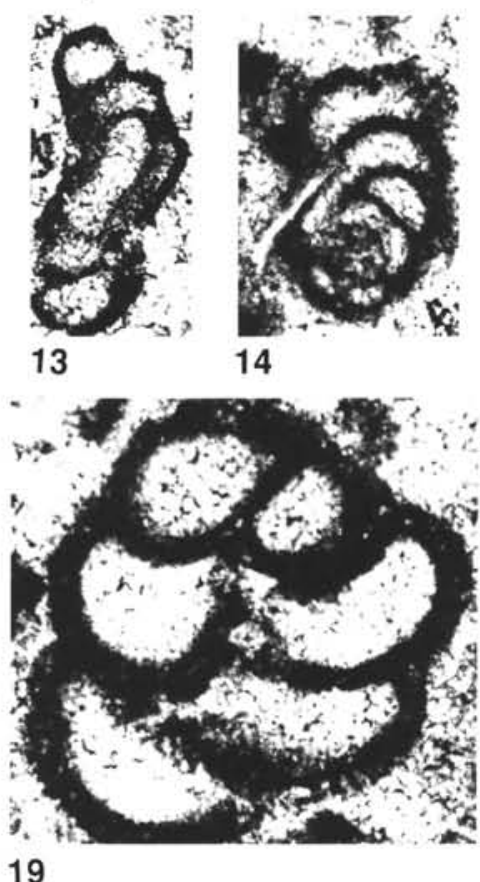
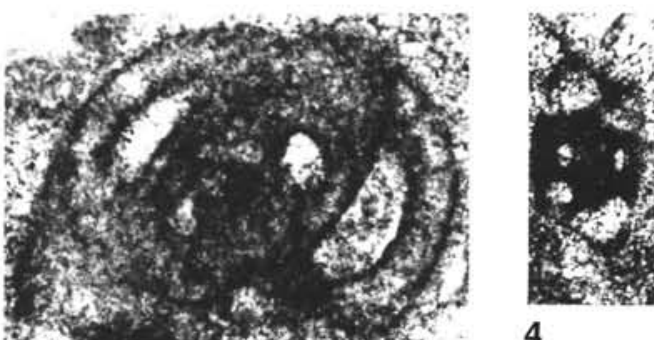

3
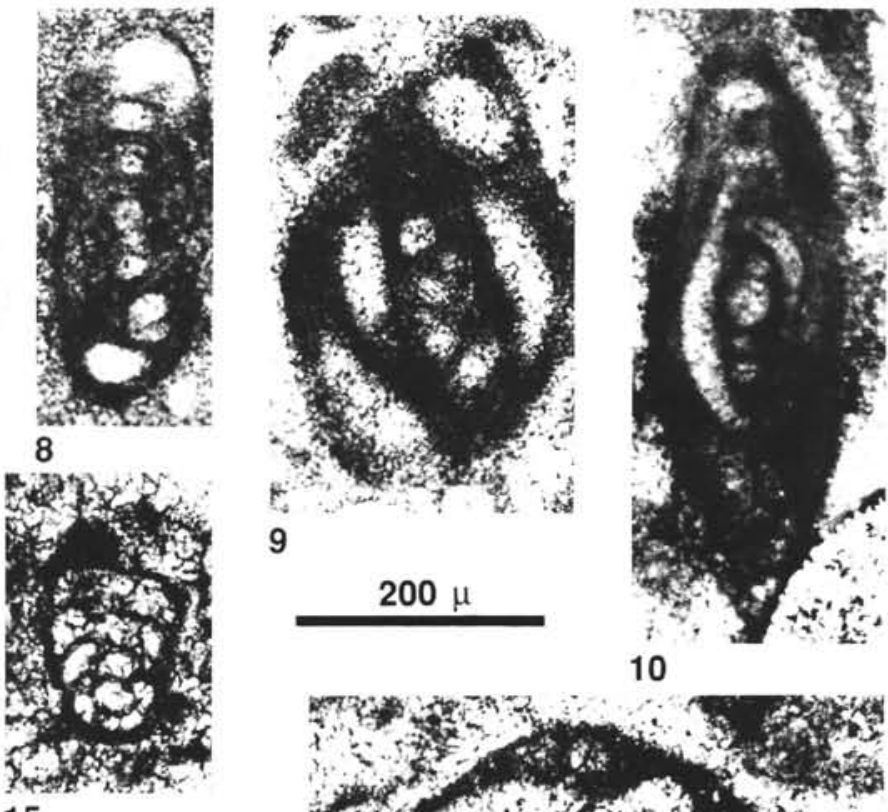

10

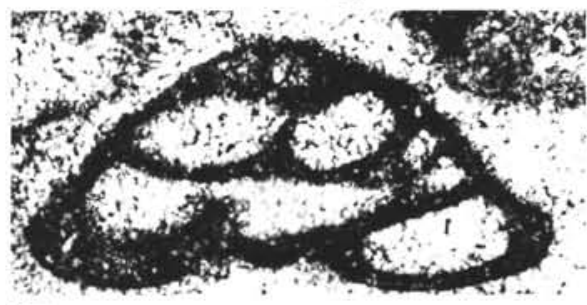

17

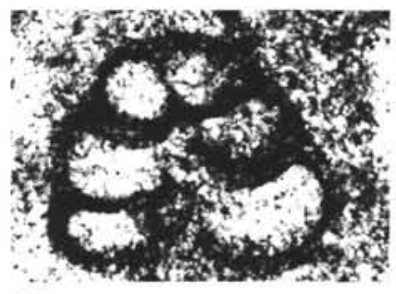

21

Plate 5. 1-3, 5. Galeanella? laticarinata Al-Shaibani, Carter, and Zaninetti; (1-3) Sample 122-764B-23R-1, 72-76 cm, (5) Sample 122-764B-24R-CC, 1-4 cm. 4. Miliolidae? indet., Sample 122-764B-20R-1, 94-98 cm. 6, 7. Planiinvoluta carinata Leischner; (6) Sample 122-764B-8R-CC, 4-8 cm, (7) Sample 122-764B-7R-1, 12-14 cm. 8-10. Ophthalmidium spp.; (8) Sample 122-764B-20R-1, 94-98 cm, (9) Sample 122-764B-20R-1, 37-40 cm, (10) Sample 122-764B-20R-1, 72-76 cm. 11. Indeterminate foraminifer with two-layered wall, Sample 122-764B-7R-1, 12-14 cm. 12-15. Indeterminate foraminifers; $(12,13,15)$ Sample 122-764B-7R-1, 12-14 cm, (14) Sample 122-764B-14R-CC, 5-8 cm. 16. Trocholina sp., Sample 122-764B-27R-1, 60-64 cm. 17, 19-21. "Tetrataxis" inflata Kristan, Sample 122-764B-14R-CC, 5-8 cm. 18. Endothyridae, Sample $122-764 B-14 R-C C, 5-8 \mathrm{~cm}$. 